University of Nebraska - Lincoln

DigitalCommons@University of Nebraska - Lincoln

1999

\title{
Iron-Mediated Remediation of RDX-Contaminated Water and Soil under Controlled Eh/pH
}

\author{
J. Singh \\ University of Nebraska - Lincoln \\ Steven Comfort \\ University of Nebraska - Lincoln, scomfort1@unl.edu \\ Patrick Shea \\ University of Nebraska - Lincoln, pshea1@unl.edu
}

Follow this and additional works at: https://digitalcommons.unl.edu/natrespapers

Part of the Natural Resources and Conservation Commons

Singh, J.; Comfort, Steven; and Shea, Patrick, "Iron-Mediated Remediation of RDX-Contaminated Water and Soil under Controlled Eh/pH" (1999). Papers in Natural Resources. 148.

https://digitalcommons.unl.edu/natrespapers/148

This Article is brought to you for free and open access by the Natural Resources, School of at DigitalCommons@University of Nebraska - Lincoln. It has been accepted for inclusion in Papers in Natural Resources by an authorized administrator of DigitalCommons@University of Nebraska - Lincoln. 


\section{Iron-Mediated Remediation of RDX- Contaminated Water and Soil under Controlled Eh/pH}

- Abstract

- Full Text HTML

- Ui-Res PDF[233 KB]

J. Singh, S. D. Comfort,*- and P. J. Shea

School of Natural Resource Sciences, University of Nebraska, Lincoln, Nebraska 68583-0915

Environ. Sci. Technol., 1999, 33 (9), pp 1488-1494

DOI: $10.1021 /$ es9806175

Publication Date (Web): March 24, 1999

Copyright (C) 1999 American Chemical Society

* Corresponding author phone: (402)472-1502; fax: (402)472-7904; e-mail: scomfort@unl.edu.

Soil and water contaminated with hexahydro-1,3,5-trinitro-1,3,5-triazine (RDX) is a serious environmental problem at several active and abandoned munitions production facilities. Zero-valent iron $\left(\mathrm{Fe}^{0}\right)$ can effectively remediate RDX-contaminated soil and water. The objective of this study was to manipulate $\mathrm{Eh}$ and $\mathrm{pH}$ for enhanced $\mathrm{Fe}^{0}$-mediated destruction of RDX. This was accomplished by monitoring RDX destruction under controlled Eh-pH conditions (Eh: -300 to $+150 \mathrm{mV} ; \mathrm{pH}: 2-10$ ). Decreasing Eh and $\mathrm{pH}$ increased RDX destruction in aqueous solution. Treating $20 \mathrm{mg}$ of $\mathrm{RDX} \mathrm{L}^{-1}(90 \mu \mathrm{M})$ under a static Eh of $-150 \mathrm{mV}$ and $\mathrm{pH} 7$ with $20 \mathrm{~g}$ of $\mathrm{Fe}^{0} \mathrm{~L}^{-1}$ removed $95 \%$ of the RDX within $4 \mathrm{~h}$; no RDX was detected after $8 \mathrm{~h}$. Treating a soil slurry ( $20 \%$ solids; $510 \mathrm{mg} \mathrm{RDX} \mathrm{kg}^{-1}$ soil) with $20 \mathrm{~g}^{\circ} \mathrm{Fe}^{0} \mathrm{~L}^{-1}$ at an Eh of $-150 \mathrm{mV}$ and $\mathrm{pH} 7$ increased RDX destruction by $24 \%$ over the unbuffered control and resulted in 99\% RDX destruction within $24 \mathrm{~h}$. Adding $4.2 \mathrm{mM}$ sodium sulfide (in lieu of a static Eh) under similar conditions resulted in 93\% RDX loss within $24 \mathrm{~h}$. Results indicated that lowering Eh and maintaining neutral $\mathrm{pH}$ during $\mathrm{Fe}^{0}$ treatment can increase RDX destruction in contaminated soil and water.

In accordance with ACS policy, only the figures and tables may be included in this archive. The full text of the article is available at http://pubs.acs.org/doi/abs/10.1021/es9806175 


$\begin{aligned} & \text { TABLE 1. Characteristics of RDX-Contaminated Soil Obtained } \\
& \text { from the Former Nebraska Ordnance Plant near Mead, NE }\end{aligned}$
\begin{tabular}{llc}
\multicolumn{1}{c}{ soil property } & \multicolumn{1}{c}{ unit } & RDX-contaminated soil \\
soil $\mathrm{pH}\left(1: 1, \mathrm{H}_{2} \mathrm{O}\right)$ & & 5.9 \\
organic carbon & $\%$ & 1.6 \\
cation exchange capacity & $\mathrm{cmol}_{\mathrm{c}} \mathrm{kg}^{-1}$ & 15.4 \\
sand & $\%$ & 30 \\
silt & $\%$ & 46 \\
clay & $\%$ & 24 \\
extractable RDX & $\mathrm{mg} \mathrm{kg}^{-1}$ & 510 \\
\hline
\end{tabular}



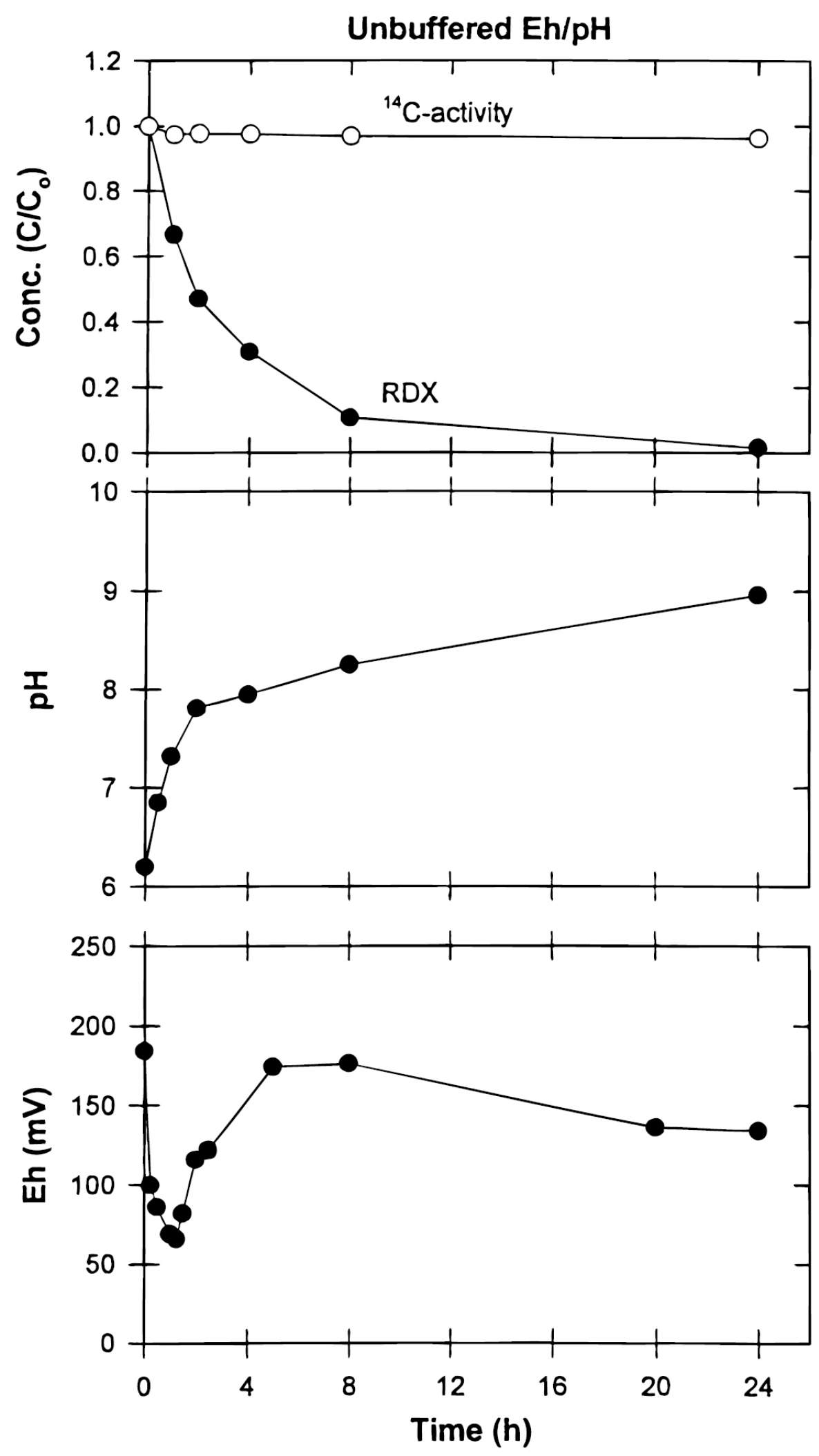

FIGURE 1. Changes in RDX, ${ }^{14} \mathrm{C}$-activity, Eh, and $\mathrm{pH}$ with time following addition of $20 \mathrm{~g} \mathrm{Fe}^{0} \mathrm{~L}^{-1}(2 \%, \mathrm{w} / \mathrm{v})$ to a $20 \mathrm{mg} \mathrm{RDX} \mathrm{\textrm {L } ^ { - 1 }}$ aqueous solution. 


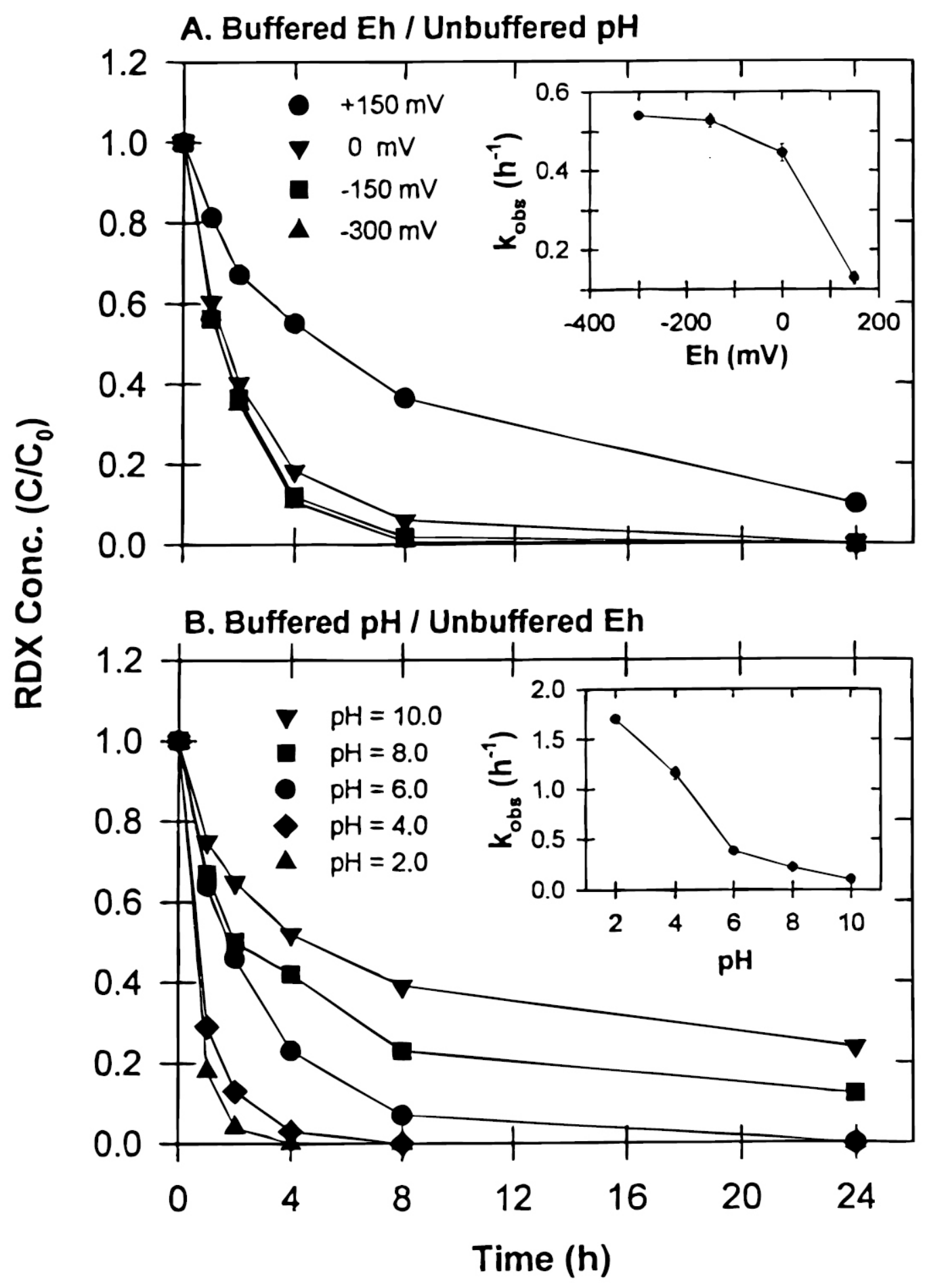

FIGURE 2. Changes in RDX concentration following $\mathrm{Fe}^{0}$ treatment under buffered: (A) Eh $(+150,0,-150$, and $-300 \mathrm{mV})$ and $(B) \mathrm{pH}$ $(10,8,6,4,2)$. 

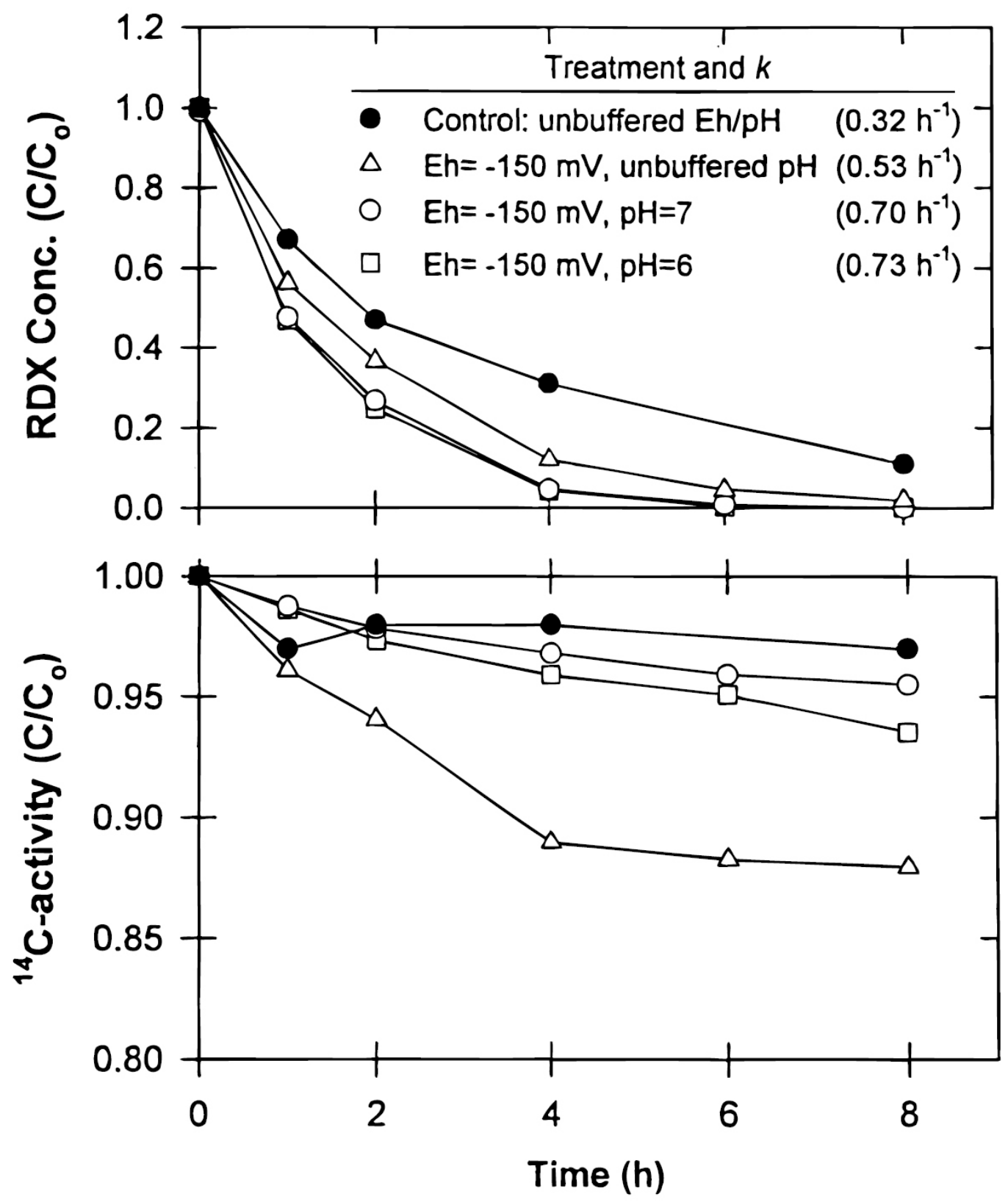

FIGURE 3. Changes in RDX concentrations and ${ }^{14} \mathrm{C}$-activity under controlled Eh/pH conditions. 

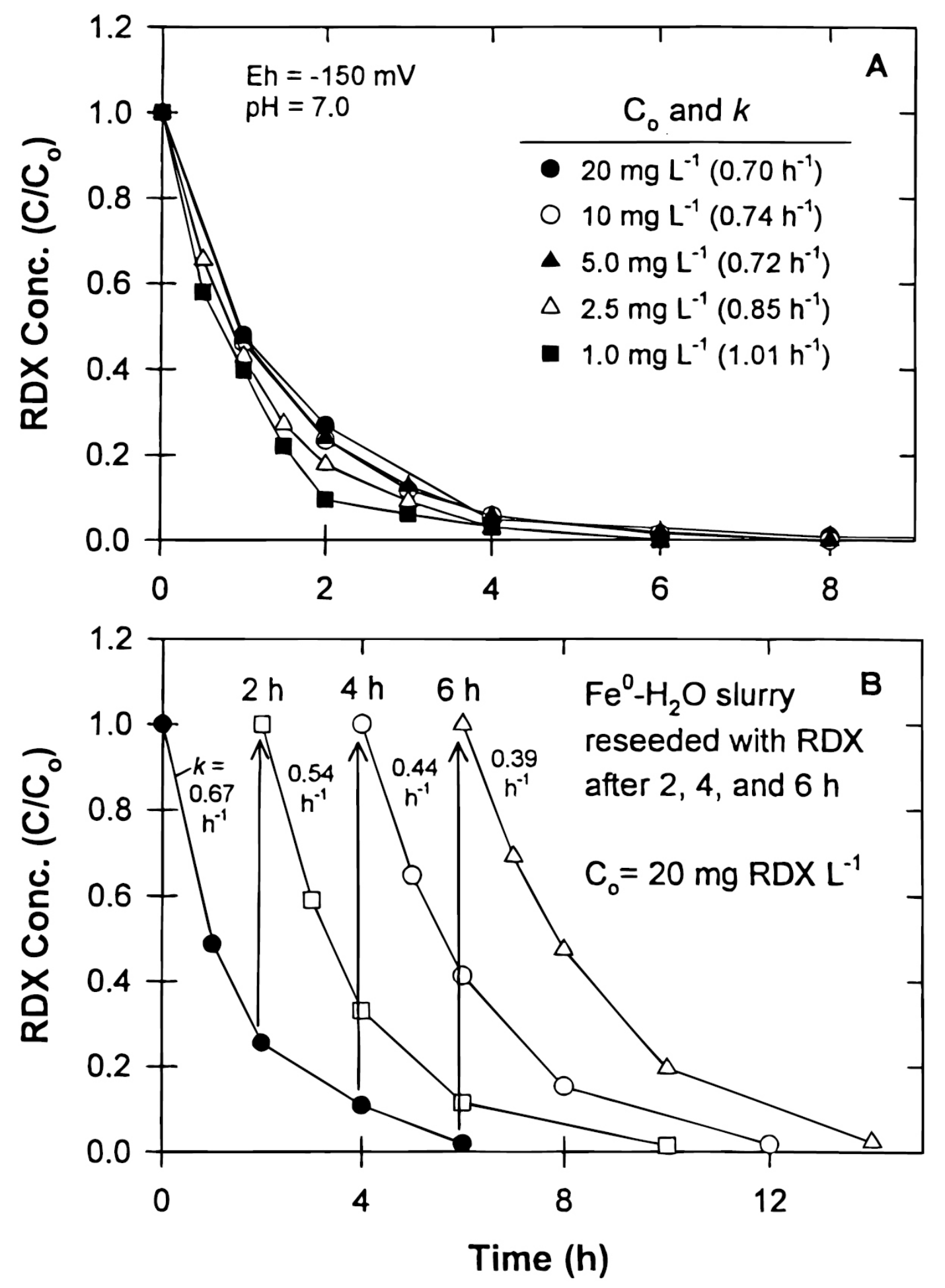

FIGURE 4. Changes in RDX concentrations following $\mathrm{Fe}^{0}$ addition: (A) effects of initial RDX concentration on pseudo first-order destruction rates; and (B) effects of iron aging on RDX destruction rates. The figure indicates results from three experiments where RDX was reseeded into the reaction cell after 2,4 , and $6 \mathrm{~h}$. 


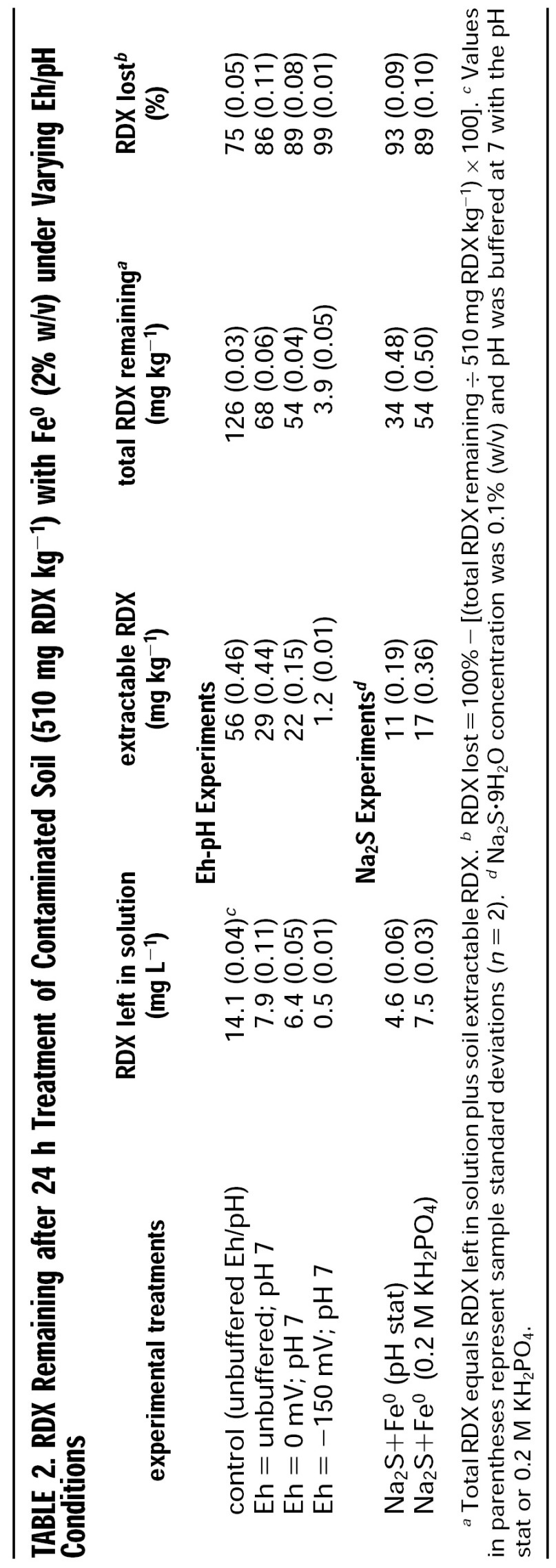


$\mathrm{Fe}^{0}$ Treatment of Soil Slurry
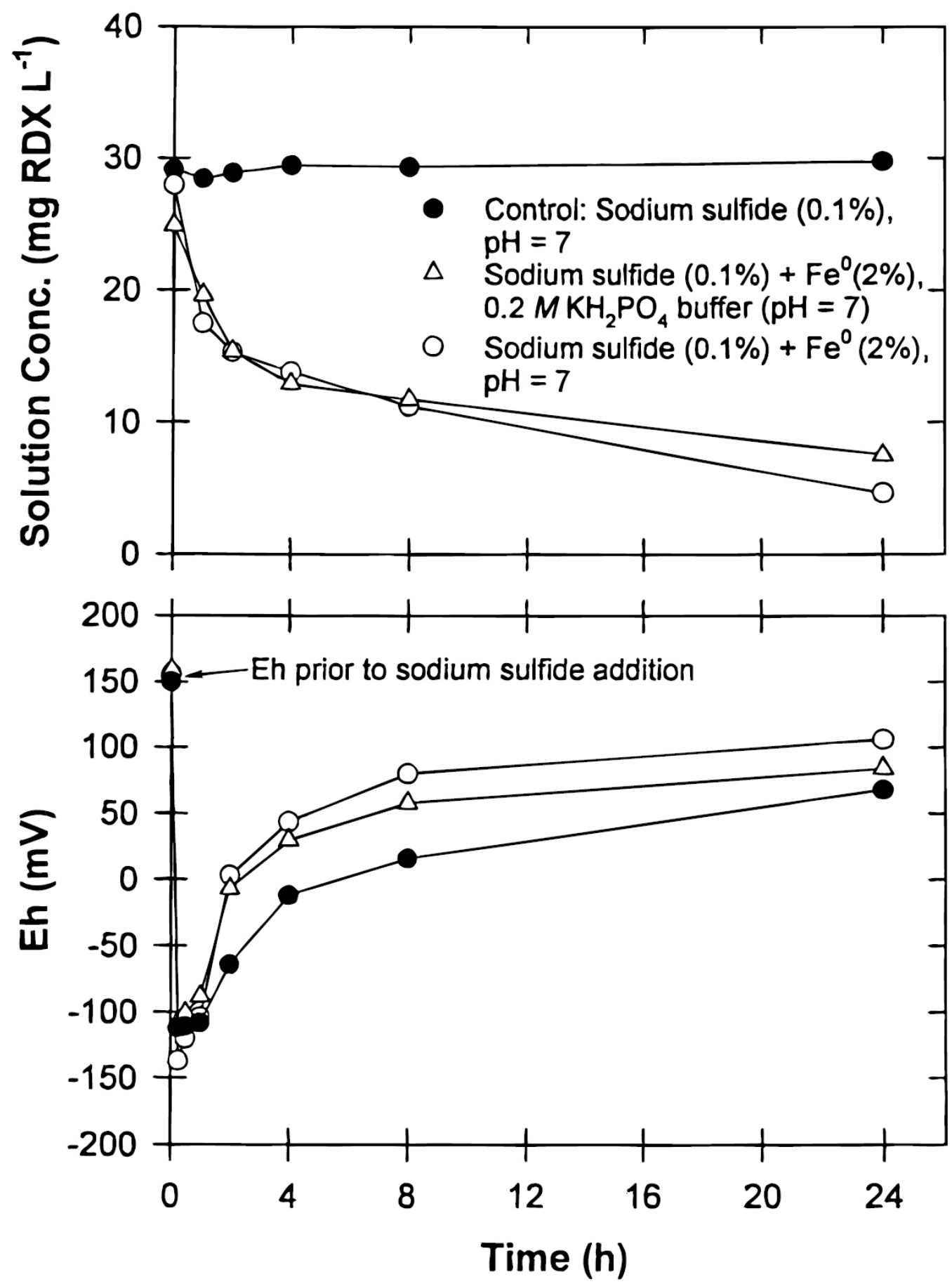

FIGURE 5. Changes in RDX concentration and Eh following treatment of a soil slurry with $\mathrm{Fe}^{0}$. Eh was lowered by $\mathrm{Na}_{2} \mathrm{~S} \cdot 9 \mathrm{H}_{2} \mathrm{O}$ addition, and $\mathrm{pH}$ was controlled by the $\mathrm{pH}$-stat or phosphate buffer. 